\title{
Wykładnia art. 14 ust. 3 ustawy o sejmowej komisji śledczej oraz art. 15 § 2 Kodeksu postępowania karnego'
}

Interpretation of Article 14 para. 3 of the Act on the Sejm Investigative Committees and Article 15 para. 2 of the Code of Criminal Procedure: The author analyses the above-mentioned provisions, discussing the problem of a potential disclosure of documents and other materials collected by an investigative committee to authorities conducting criminal proceedings. In case of a convergence between the investigation conducted by the Central Anticorruption Bureau (CAB) and the matter examined by the investigative committee there are no formal obstacles to the realisation of a request for on submission of materials concerning the work of the committee to the CAB.

Keywords: investigative Committee, Code of Criminal Procedure, state prosecution, Central Anticorruption Bureau

Słowa kluczowe: komisja śledcza, Kodeks postępowania karnego, prokuratura, Centralne Biuro Antykorupcyjne

Ekspert ds. legislacji BAS - wojciech.sypniewski@sejm.gov.pl • https://orcid.org/0000-0002-7704-5042

\section{Przedmiot opinii}

Przedmiotem opinii są odpowiedzi na pytania wynikające z pisma Szefa Centralnego Biura Antykorupcyjnego. Na podstawie art. $15 \$ 2$ Kodeksu postępowania karnego wystąpił on do Komisji śledczej do zbadania prawidłowości i legalności działań oraz występowania zaniedbań i zaniechań organów i instytucji publicz-

\footnotetext{
Opinia prawna na temat wykładni art. 14 ust. 3 ustawy o sejmowej komisji śledczej oraz art. $15 \$ 2 \mathrm{kpk}$ sporządzona 5 grudnia 2018 r. na zlecenie Komisji śledczej do zbadania prawidłowości i legalności działań oraz występowania zaniedbań i zaniechań organów i instytucji publicznych w zakresie zapewnienia dochodów Skarbu Państwa $\mathrm{z}$ tytułu podatku od towarów i usług i podatku akcyzowego w okresie od grudnia 2007 r. do listopada 2015 r. (SKVAT); BAS-WAKiU 2800/18.
} 
nych w zakresie zapewnienia dochodów Skarbu Państwa z tytułu podatku od towarów i usług i podatku akcyzowego w okresie od grudnia $2007 \mathrm{r}$. do listopada 2015 r. (dalej: SKVAT) o przekazanie na potrzeby śledztwa prowadzonego przez CBA pod nadzorem prokuratury „dotychczas zebranych przez Komisję Śledczą materiałów” oraz "bieżące i systematyczne przekazywanie materiałów z prac komisji, celem wykorzystania ich w śledztwie”. W treści pisma Szefa CBA nie zostały wskazane konkretne dokumenty będące w posiadaniu Komisji, których pozyskaniem CBA jest zainteresowane, oraz nie zostały określone okoliczności, które miałyby przemawiać za koniecznością pozyskania tych dokumentów dla dobra prowadzonego postępowania.

W związku z przedstawionymi faktami sformułowano następujące pytania:

- Czy Komisja śledcza może udostępnić posiadane przez siebie materiały w innym trybie niż określony w art. 14 ust. 3 ustawy o sejmowej komisji śledczej zdanie drugie?

- Czy Centralne Biuro Antykorupcyjne działające pod nadzorem Prokuratury jest, zgodnie z brzmieniem art. 14 ust. 3 ustawy o sejmowej komisji śledczej, ,innym organem władzy publicznej”, a co za tym idzie czy konieczne jest w tym wypadku uzyskanie zgody Marszałka Sejmu na przekazanie materialów?

- Czy ewentualne przekazanie musi być uzasadnione przesłanką nieodzowności/konieczności materiałów dla dobra prowadzonego postępowania, czy wystarczy wykazać związek tych materiałów z toczącym się postępowaniem karnym?

- Czy przesłanka konieczności dla dobra prowadzonego postępowania może być wykazana generalnie dla materiałów określonych w sposób ogólny, czy tylko dla dokumentów konkretnie wskazanych, chociażby w spisie dokumentów wnioskowanych?

- Czy spełnienie prośby o „bieżące i systematyczne przekazywanie materiałów z prac komisji" znajduje oparcie w prawie, czy raczej należałoby oczekiwać od CBA, aby występowało z kolejnymi wnioskami o przekazanie kolejnych dokumentów zgromadzonych przez Komisję?

\section{Udostępnianie materiałów zebranych przez komisję śledczą na wniosek sądu lub prokuratora}

1. W myśl art. $15 \$ 2$ Kodeksu postępowania karnego ${ }^{2}$ : wszystkie instytucje państwowe i samorzadowe sq obowiazane w zakresie swego działania do udzielania pomocy organom prowadzacym postępowanie karne $w$ terminie wyznaczonym przez te

2 Ustawa z 6 czerwca 1997 r. - Kodeks postępowania karnego, t.j. Dz.U. 2018, poz. 1987, ze zm.; dalej: k.p.k. 
organy. Zgodnie z $\$ 3$ tego samego artykułu: osoby prawne lub jednostki organizacyjne niemające osobowości prawnej inne niż określone $w \$ 2$, a także osoby fizyczne sq obowiązane do udzielenia pomocy na wezwanie organów prowadzacych postępowanie karne $w$ zakresie i $w$ terminie przez nie wyznaczonym, jeżeli bez tej pomocy przeprowadzenie czynności procesowej jest niemożliwe albo znacznie utrudnione.

W piśmiennictwie wskazuje się, że ze sformułowania zawartego w art. $15 \$ 2$ k.p.k.: wynika w sposób oczywisty, że obowiązek ten dotyczy wyłacznie udzielenia pomocy w zakresie prowadzonego postępowania karnego. [...] Żądanie pomocy nie może przekraczać zakresu działania danych instytucji. Udzielenie pomocy $w$ rozumieniu $\$ 2$ nie obejmuje obowiązku współdziałania $w$ ramach tzw. czynności operacyjno-rozpoznawczych ${ }^{3}$. Powołany autor uważa, że pojęcie „instytucji państwowych i samorządowych" obejmuje wszystkie instytucje prawa publicznego, którym przysługują kompetencje z zakresu wykonywania władzy publicznej. Do innych osób prawnych i jednostek organizacyjnych, w tym podmiotów prawa prywatnego, nawet jeżeli utworzone zostały przez organy państwowe lub samorządowe, zastosowanie ma przepis art. $15 \$ 3$ k.p.k. W ocenie S. Steinborna podmioty, o których mowa $\mathrm{w} \$ 2$ : nie moga być obarczane obowiązkiem dokonywania ustaleń faktycznych w postępowaniu karnym, który obciąża organy procesowe. Udzielenie pomocy jest wówczas uzasadnione, gdy dokonanie określonej czynności przez organ procesowy jest znacznie utrudnione lub niemożliwe, zaś specyfika funkcjonowania instytucji udzielającej pomocy zapewnia jej sprawne i profesjonalne przeprowadzenie. Uwzględnić należy także okoliczność, że jeżeli określona czynność instytucji udzielającej pomocy nie ma charakteru czynności procesowej (a więc wymagającej zachowania określonych rygorów formalnych), nie może ona być $w$ toku dalszego postępowania podstawa dokonania ustaleń faktycznych. Czynność podjęta $w$ trybie „pomocy” przewidzianej $w$ art. $15 \$ 2$, jeżeli ujawnia istotne okoliczności mogące być podstawa ustaleń faktycznych, powinna być dla organu procesowego impulsem dla podjęcia działań w celu jej zabezpieczenia i przeksztatcenia $w$ materiat dowodowy $w$ wymaganej przez ustawe formie ${ }^{4}$.

Obligacyjny wymiar obowiązków, o których mowa w art. $15 \$ 2$ i 3 k.p.k., wzmocniony został możliwością nałożenia sankcji za ich niewykonanie. Odpowiednie zastosowanie zgodnie z art. 287 k.p.k. znajdzie art. 285 k.p.k., pozwalający na nałożenie kary pieniężnej w wysokości do 3000 zł na przedstawiciela lub kierownika instytucji, osoby prawnej lub jednostki organizacyjnej niemającej osobowości prawnej obowiązanej udzielić pomocy organowi prowadzącemu postępowanie karne, który bezpodstawnie nie udziela pomocy w wyznaczonym terminie. W postępowaniu przygotowawczym karę tę nakłada prokurator (art. $290 \$ 1$ zdanie pierwsze k.p.k.).

3 S. Steinborn [w:] Kodeks postępowania karnego. Komentarz do wybranych przepisów, red. S. Steinborn, 2016, LEX.

4 Ibidem. 
Powoływany autor wskazuje, że obowiązek udzielenia pomocy organom procesowym przez instytucje państwowe i samorządowe może wynikać również z przepisów szczególnych. Sygnalizowane przez niego przykłady obejmują:

- art. 23 ust. 1 pkt 7 i 8 w związku z art. 21 ust. 1 oraz art. 24 ust. 1 ustawy z 24 maja 2002 r. o Agencji Bezpieczeństwa Wewnętrznego oraz Agencji Wywiadu (t.j. Dz.U. 2017, poz. 192, ze zm.), które pozwalają funkcjonariuszom Agencji Bezpieczeństwa Wewnętrznego w ramach wykonywania czynności operacyjno-rozpoznawczych, dochodzeniowo-śledczych i analityczno-informacyjnych oraz funkcjonariuszom Agencji Wywiadu wykonującym czynności rozpoznawcze i analityczno-informacyjne m.in. na:

- żądanie niezbędnej pomocy od instytucji państwowych, organów administracji rządowej i samorządu terytorialnego oraz przedsiębiorców prowadzących działalność w zakresie użyteczności publicznej; wymienione instytucje, organy i przedsiębiorcy są obowiązani, w zakresie swojego działania, do udzielania tej pomocy nieodpłatnie, w ramach obowiązujących przepisów prawa,

- zwracanie się o niezbędną pomoc do innych, niż wymienione, przedsiębiorców, jednostek organizacyjnych i organizacji społecznych, jak również zwracania się w nagłych wypadkach do każdej osoby o udzielenie doraźnej pomocy, w ramach obowiązujących przepisów prawa,

- przepisy art. 105-106 ustawy z 29 sierpnia 1997 r. - Prawo bankowe (t.j. Dz.U. 2017, poz. 1876, ze zm.), które pozwalają na uchylenie tajemnicy bankowej i udzielanie informacji dla celów prowadzonego postępowania karnego na żądanie sądu lub prokuratora,

- art. 52 ustawy z 18 grudnia 1998 r. o Instytucie Pamięci Narodowej - Komisji Ścigania Zbrodni przeciwko Narodowi Polskiemu (t.j. Dz.U. 2018, poz. 2032), który przewiduje, że organy wymiaru sprawiedliwości, prokuratury, organy i jednostki organizacyjne podległe, nadzorowane lub podporządkowane $\mathrm{Mi}$ nistrowi Spraw Wewnętrznych i Administracji, Ministrowi Obrony Narodowej, Ministrowi Spraw Zagranicznych i Szefowi Urzędu Ochrony Państwa oraz organy administracji rządowej i samorządu terytorialnego są obowiązane, każdy w zakresie swojego działania, do udzielania pomocy Instytutowi Pamięci Narodowej w realizacji jego zadań.

2. W myśl art. 14 ust. 3 ustawy z 21 stycznia 1999 r. o sejmowej komisji śledczej (Dz.U. 2016, poz. 1024; dalej: ustawa o sejmowej komisji śledczej lub ustawa): na wniosek sądu lub prokuratora komisja udostępnia tym organom zebrane przez siebie materiały, jeżeli pozostaja one $w$ związku z toczącym się postępowaniem karnym; komisja, za zgoda Marszałka Sejmu, może udostępnić zebrane materiały, jeżeli uzna to za konieczne dla dobra postępowania prowadzonego przez inne organy władzy publicznej. Powołany przepis w zdaniu pierwszym nakłada na komisję obowiązek udostępnienia materiałów zebranych w trakcie prac są- 
dom i prokuraturze. Obwiązek ten materializuje się wówczas, gdy (a) zostanie złożony przez uprawniony podmiot wniosek w tej sprawie (wniosek powinien być dostarczony Marszałkowi Sejmu albo przewodniczącemu komisji śledczej, który zgodnie z art. 10 ust. 2 reprezentuje ją na zewnątrz) oraz (b) gdy materiały objęte zakresem wniosku pozostają $\mathrm{w}$ związku $\mathrm{z}$ toczącym się postępowaniem karnym. Treść tego przepisu wskazuje, że podmiot występujący z wnioskiem: powinien przynajmniej uprawdopodobnić we wniosku związek toczacego się postępowania karnego z postępowaniem prowadzonym przez komisję lub materiałami przez niq zebranymi ${ }^{5}$.

3. Należy uznać, że art. 14 ust. 3 zdanie pierwsze ustawy o sejmowej komisji śledczej jest przepisem szczególnym w odniesieniu do art. $15 \$ 2$ k.p.k. w zakresie, w jakim przepis ten określa zasady udzielania pomocy organom prowadzącym postępowanie karne polegającej na udostępnianiu materiałów zebranych przez komisję śledczą. Od strony formalnej zauważyć należy, że przepis ten luzuje wymóg zachowania terminu wskazanego przez organ domagający się udzielania pomocy. Z treści art. 14 ust. 3 ustawy nie wynika, by wnioskodawca mógł zobowiązać komisję do udostępniania żądanych materiałów w ściśle określonym terminie. Nie będzie miała również zastosowania sankcja za niewykonanie tego obowiązku (art. 287 w związku z art. 285 k.p.k.). Z drugiej strony użycie terminu „wniosek” wskazuje na konieczność zachowania formy pisemnej, co w przypadku art. $15 \$ 2$ k.p.k. nie wynika expressis verbis z treści tego przepisu ${ }^{6}$.

Bardziej doniosłe modyfikacje zdają się wynikać z wyeksponowanego $\mathrm{w}$ art. 14 ust. 3 zdanie pierwsze ustawy warunku, by materiały objęte wnioskiem pozostawały „w związku z toczącym się postępowaniem karnym”. Pozornie można by sądzić, że „obiektywny” charakter tego wymogu powoduje, iż komisji przysługuje prawo oceny, czy przesłanka ta została w konkretnym przypadku spełniona. Pogląd ten należy uznać jednak tylko za częściowo trafny. Zasadna wydaje się bowiem teza, że wnioskodawca powinien uzasadnić potrzebę pozyskania materiałów zgromadzonych przez komisję dla potrzeb prowadzonego postępowania karnego. Nie oznacza to jednak, że poza przypadkami ewidentnymi komisja mogłaby odmawiać udostępniania materiałów z uwagi, na to, że w jej ocenie nie zachodzi związek pomiędzy zgromadzonym materiałem dowodowym a postępowaniem karnym prowadzonym przez sąd lub prokuraturę.

Zasada jawności (publiczności) w procesie karnym znajduje zastosowanie w ściśle określonych ramach ${ }^{7}$. Również jawność postępowania prowadzonego przez komisję napotyka wyraźne ograniczenia ustawowe (art. 11h ust. 2 oraz

5 T. Osiński, Komentarz do art. 14 [w:] M. Lewandowski, A. Kowalski, T. Osiński, Sejmowa komisja śledcza. Ustawa z 1999 r. z komentarzem, Warszawa 2006, s. 192.

6 Por. uwagi S. Steinborna [w:] Kodeks postępowania karnego, op. cit.

7 Postępowanie przygotowawcze - odmiennie niż postępowanie sądowe - nie jest oparte na zasadzie pełnej jawności akt sprawy; zob. art. 156 k.p.k. 
art. 16 ustawy). W konsekwencji ani organ prowadzący postępowanie karne nie ma pełnej wiedzy na temat materiałów zgromadzonych przez komisję, ani komisja śledcza nie zna treści materiału dowodowego zgromadzonego w postępowaniu karnym, które w ocenie prokuratury pozostaje w związku ze śledztwem sejmowym. Ocena, czy materiały objęte wnioskiem będą rzeczywiście przydatne w konkretnym postępowaniu karnym, może być w praktyce dokonana przez organ, który je prowadzi po przekazaniu tych materiałów. „Związek materiałów zebranych przez komisję z toczącym się postępowaniem karnym”, o którym mowa $\mathrm{w}$ art. 14 ust. 3 ustawy, należy zatem postrzegać w kategoriach bardzo ogólnych. Jak zauważył Trybunał Konstytucyjny w wyroku z 14 kwietnia 1999 r., sygn. akt K 8/99, celem postępowania sądowego w sprawie karnej jest rozstrzygnięcie o odpowiedzialności karnej danej osoby. Natomiast celem komisji śledczej jest zbadanie działalności danego organu władzy publicznej, a w szczególności ustalenie zakresu i przyczyn nieprawidłowości w jego funkcjonowaniu. Zebranie informacji umożliwia Sejmowi podjęcie niezbędnych kroków politycznych w celu przeciwdziałania nieprawidłowościom i usprawnienia działania aparatu państwowego. Zbieżność merytoryczna sprawy badanej przez komisję z przedmiotem konkretnego postępowania karnego zaistnieje wówczas, gdy zarówno komisja, jak i prokuratura badać będą zbieżne okoliczności faktyczne. O ile jednak zadaniem prokuratury jest ocena, czy został popełniony czyn zabroniony oraz zgromadzenie dowodów pozwalających na ustalenie sprawcy i pociągnięcie go do odpowiedzialności w związku z naruszeniem normy prawa karnego, o tyle celem komisji śledczej jest ustalenie przyczyn ewentualnych nieprawidłowości w działaniach organów władzy publicznej. Należy zatem uznać, że obowiązek udostępnienia objętych wnioskiem materiałów istnieć będzie we wszystkich tych przypadkach, w których pomiędzy toczącym się postępowaniem karnym a sprawą badaną przez komisję zachodzić będzie ogólny związek merytoryczny polegający na zbieżności czasu i miejsca badanych zdarzeń oraz tożsamości osób w nich uczestniczących.

\section{Odpowiedzi na pytania}

Ad 1. Podstawą prawną udostępniania materiałów zebranych przez komisję na wniosek sądu lub prokuratora jest art. 14 ust. 3 ustawy o sejmowej komisji śledczej. Jest on przepisem szczególnym względem art. $15 \$ 2$ k.p.k. Wskazanie w piśmie CBA jedynie ogólnej podstawy prawnej (art. $15 \$ 2$ k.p.k.) nie uchyla obowiązku wynikającego z art. 14 ust. 3 ustawy o sejmowej komisji śledczej. Wniosek CBA powinien jednak w uzasadnieniu uprawdopodobniać istnienie zbieżności pomiędzy śledztwem prowadzonym przez CBA a sprawą badaną przez komisję.

Ad 2-4. Prokurator - w zakresie określonym w art. $311 \S 2$ k.p.k. - może powierzyć Policji przeprowadzenie śledztwa w całości lub w określonym zakre- 
sie albo dokonanie poszczególnych czynności śledztwa. Jeżeli prokurator powierzył Policji prowadzenie śledztwa w całości, to może ona podejmować wszelkie czynności procesowe (chyba że z mocy przepisu szczególnego zastrzeżone zostały one do właściwości innego organu). Zasady powierzania prowadzenia śledztwa określone w art. 311 k.p.k. znajdują zastosowanie do powierzania śledztwa organom Centralnego Biura Antykorupcyjnego w zakresie jego właściwości (art. 312 pkt 1 k.p.k.). W konsekwencji CBA prowadzące śledztwo powierzone przez prokuratora może korzystać z uprawnień przysługujących temu organowi na podstawie art. 14 ust. 3 ustawy. W takim wypadku właściwą podstawą prawną udostępnienia materiałów przez komisję śledczą jest art. 14 ust. 3 zdanie pierwsze ustawy nie zaś art. 14 ust. 3 zdanie drugie. Przesłanki warunkujące udostępnienie zebranych materiałów na użytek postępowań prowadzonych przez inne organy nie mają zatem zastosowania. Oznacza to, że warunkiem udostępnienia dokumentów zgromadzonych przez komisję sądowi, prokuratorowi (czy CBA prowadzącemu śledztwo powierzone przez prokuratora) nie jest „konieczność dla dobra postępowania” czy zgoda Marszałka Sejmu, bowiem ograniczenia te dotyczą udostępnienia materiałów komisji śledczej organom innym niż organy wykonujące czynności procesowe.

Ad 5. W sytuacji, w której zachodzi zbieżność pomiędzy śledztwem prowadzonym przez CBA i sprawą badaną przez komisję, która wskazuje na istnienie związku materiałów gromadzonych w śledztwie sejmowym $\mathrm{z}$ toczącym się postępowaniem karnym, należy uznać, że nie ma formalnych przeszkód dla realizacji wniosku o systematyczne przekazywanie materiałów z prac komisji.

\section{Podsumowanie}

- Podstawą prawną udostępniania materiałów zebranych przez komisję na wniosek sądu lub prokuratora jest art. 14 ust. 3 ustawy o sejmowej komisji śledczej. Jest on przepisem szczególnym względem art. $15 \$ 2$ k.p.k. Wskazanie w piśmie CBA jedynie ogólnej podstawy prawnej (art. $15 \$ 2$ k.p.k.) nie uchyla obowiązku wynikającego z art. 14 ust. 3 ustawy o sejmowej komisji śledczej. Wniosek CBA powinien jednak w uzasadnieniu uprawdopodobniać istnienie zbieżności pomiędzy śledztwem prowadzonym przez CBA a sprawą badaną przez komisję. - Prokurator - w zakresie określonym w art. $311 \$ 2$ k.p.k. - może powierzyć Policji przeprowadzenie śledztwa w całości lub w określonym zakresie albo dokonanie poszczególnych czynności śledztwa. Zasady powierzania prowadzenia śledztwa określone w art. 311 k.p.k. znajdują zastosowanie do powierzania śledztwa organom Centralnego Biura Antykorupcyjnego w zakresie jego właściwości (art. 312 pkt 1 k.p.k.). W konsekwencji CBA prowadzące śledztwo powierzone przez prokuratura może korzystać z uprawnień przysługujących temu organowi na podstawie art. 14 ust. 3 ustawy o sejmowej komisji śledczej. 
- W sytuacji, w której zachodzi zbieżność pomiędzy śledztwem prowadzonym przez CBA i sprawą badaną przez komisję (związek materiałów gromadzonych $\mathrm{w}$ śledztwie sejmowym $\mathrm{z}$ toczącym się postępowaniem karnym), należy uznać, że nie ma formalnych przeszkód dla realizacji wniosku o systematyczne przekazywanie materiałów z prac komisji.

\section{Bibliografia}

Osiński T., Komentarz do art. 14 [w:] M. Lewandowski, A. Kowalski, T. Osiński, Sejmowa komisja śledcza. Ustawa z 1999 r. z komentarzem, Warszawa 2006.

Steinborn S. [w:] Kodeks postępowania karnego. Komentarz do wybranych przepisów, red. S. Steinborn, 2016, LEX. 